\title{
Assessing the Effect of Irrigation Water Management Strategies on Napier Productivity-A Review
}

\author{
Ivan Ntege*, Nicholas Kiggundu, Joshua Wanyama, Prossie Nakawuka \\ Department of Agricultural and Bio-systems Engineering, Makerere University, Kampala, Uganda \\ Email: ^ntegeivan002@gmail.com,nicholas.kiggundu@mak.ac.ug, joshua.wanyama@mak.ac.ug,nickie.p.nakawuka@gmail.com
}

How to cite this paper: Ntege, I., Kiggundu, N., Wanyama, J. and Nakawuka, P. (2021) Assessing the Effect of Irrigation Water Management Strategies on Napier Productivity-A Review. Agricultural Sciences, 12, 1447-1461.

https://doi.org/10.4236/as.2021.1212092

Received: October 20, 2021

Accepted: December 12, 2021

Published: December 15, 2021

Copyright $\odot 2021$ by author(s) and Scientific Research Publishing Inc. This work is licensed under the Creative Commons Attribution International License (CC BY 4.0).

http://creativecommons.org/licenses/by/4.0/

\begin{abstract}
Napier, a fast growing and perennial grass has a dry matter (DM) yield potential of 78 tons/ha/yr. However, under water availability constraints Napier's yield potential reduces to 62 tons/ha/yr. In an effort to attain Napier's yield potential, irrigation management strategies have been integrated into its production to provide the highest productivity. This review assesses the effect of irrigation water management strategies on Napier productivity and also looks at future perspectives. Application of these strategies i.e., precision irrigation, deficit irrigation, and application of biophysical models, can increase Napier's yield potential to 112 tons/ha/yr. Review findings revealed that there is a need to close the knowledge gap on response of Napier productivity to different irrigation water management strategies. The future perspective explores the potential of the FAO AquaCrop model in provision of pre-season decision-making on irrigation strategies due to its relatively low cost and simplifications required in parameterization.
\end{abstract}

\section{Keywords}

Napier, Climate Change, Irrigation, Deficit irrigation, FAO AquaCrop

\section{Introduction}

Napier grass possesses many desirable characteristics, including high yield per unit area, tolerance to intermittent drought and high water use efficiency [1], making it a forage of choice. Napier grows across a wide range of agro-ecologies and soil conditions, well adopted up to $2100 \mathrm{~m}$ a.s.L, and it establishes best in areas where the average annual precipitation is between 750 and $2500 \mathrm{~mm}$, although it withstands minor dry spells. Reference [2] noted that subtropical pas- 
tures are being used extensively to fulfil the fodder needs of the animals under intensive farming system and a large percentage are under irrigation due to their high production. Frequent, erratic and prolonged droughts have caused seasonality of Napier production. Farmers are often faced with having yield reductions and failure to meet agro-pastoral demands in terms of quality and quantity [3]. To avoid risks of yield penalty, irrigation has been integrated into Napier production to provide the highest productivity [4] [5]. However, there is an information meager on response of Napier productivity to different irrigation water management strategies [6].

This paper recognizes the inadequate information to assess the response of Napier yields to different irrigation water management strategies and it aims at addressing those gaps. Subsequent sections of the paper explicitly present a detailed review on Napier production in Uganda and discuss future prospects.

\section{Napier Production}

\subsection{Background of Napier Grass}

Napier grass (Pennisetum purpureum Schumach.) also well-known as elephant or Uganda grass, is a fast-growing perennial C4 grass native to Sub-Saharan Africa that is extensively grown across the tropical regions. Napier seeds are considered inappropriate for propagation as they produce weak seedlings which are also highly heterozygous since it is open pollinated [7]. Therefore, the grass is commonly distributed by vegetative cuttings as the prevailing practice. A study conducted by [3] observed that in the Lake Victoria crescent and Eastern Highlands Agro Ecological Zones (AEZ) of Uganda among smallholder farmers showed that the most prominent forage species used for feeding livestock is Napier at 31.8\% under intensive farming system/Agro-Pastoral. Based on Napier Morphology, there are two major categories of cultivars, the normal or tall (up to $4-7 \mathrm{~m}$ ) cultivar (i.e., "Bana" and "French Cameroon") and the dwarf or semi-dwarf ( $<2 \mathrm{~m}$ ) cultivar (i.e., "Mott”). Commonly grown varieties include: 1 ) Bana grass, usually leafy and with few silica hairs, which cause irritation during handling, 2) Clone 13, very resistant to white mould disease and a high yielder but its thin stems make it difficult to establish, 3) French Cameroon, is a high yielder, established easily from canes, 4) Kakamega 1 and 2, both are high yielders though Kakamega 1 has a higher growth rate than Kakamega 2 and 5) Pakistan hybrid, which does well in dry areas [8]. Normal Napier varieties have been reported by [9] to produce twice as much yield as the dwarf ones.

\subsection{Economic Importance of Napier Grass}

In Eastern African smallholder farming communities, Napier grass is reported to be one of the most grown forage crops [7]. The fact that it can be grazed directly or made into silage or hay, makes Napier a multipurpose forage crop [10] and there are also reports of using it as food for fish, for instance for feeding tilapia and grass carp in Nepal [7]. A recent report [11] from Nigeria also indicated that 
young shoots of Napier were used as vegetable. Besides Napier's value as fodder, it can also be utilized as live markers for demarcation of river buffer zones, windbreak, and as a source of fuel when dried material [10]. In crop land management systems, it is used as a mulch to control soil erosion, weed infestation, and pest management as a trap plant [12]. Under pest management practice, there is application of a push-pull strategy which utilizes push plants as repellent intercrop and pull plants as attractant trap for insect pest control, particularly for the maize stem borer. Reference [7] observed that due to rising worldwide interest in plummeting consumption of fossil fuels and their related climate change impacts, there is increased promotion of large biomass plants like Napier as second or next-generation biofuel crops. Consequently, the potential exists for the use of Napier grass for phytoremediation purposes, after which the large harvest could go into processing plants for biofuel production. These wide-ranging uses of Napier grass provide an indication of the multiplicity of roles it could contribute to the decrease of poverty and nutritional insecurity.

\subsection{Napier Quality Variables}

\subsubsection{Nutrients}

Nutritional quality is strongly influenced by management practices and age at harvest but, on average, Napier grass is considered to contain different nutrients in samples taken from 10 - 15 weeks old plants as indicated in Figure 1.

Apart from genetics, nutritional qualities of forages are influenced by many factors including the climate [13], soil nutrition, season and grazing pressure, management [14] and fertilizer application. An important aspect for most forages is that cutting treatments and interval can have a significant impact on both yield and nutritional qualities [14]. Relatedly, [15] findings indicated that Napier's CP content was observed to decrease significantly from $28.2 \%$ to $8.8 \%$ at 40-day and 80-day cutting intervals respectively. Then again, [16] noted that

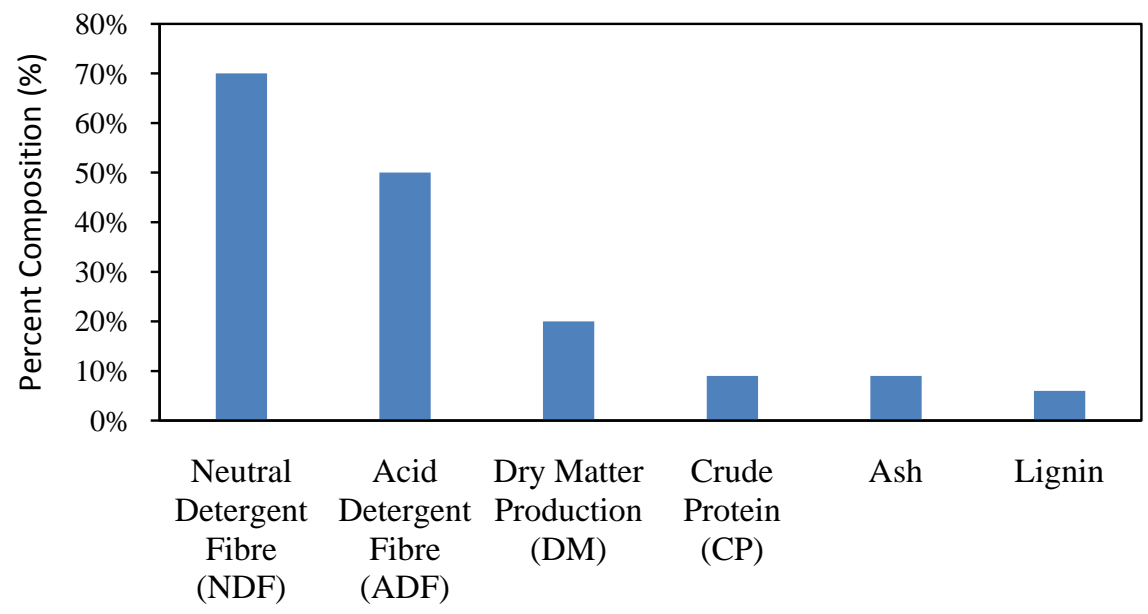

\section{Nutrients}

Figure 1. Napier nutrient composition on dry matter basis (source: [7]). 
dry matter (DM) production increases significantly over consecutive cuttings from the first to the third. The aforementioned qualities of Napier grass make it an attractive choice for livestock production systems.

\subsubsection{Yield}

Napier's potential yield mainly depends on the cultivar used which is also influenced by both the management practices employed and environment. A study conducted by [9] noted that the performance and Napier's yield is heavily influenced by agro-ecology, climatic conditions, management practices and other edaphic factors. Relatedly, [17] findings showed that the highest Napier biomass yield was obtained at non-drought location with significant variations in cultivar performance. According to [18], the most significant factors affecting Napier's DM production include environment, followed by interactions between genotype and environment and lastly genotype. Napier grass, with its perennial nature and fast growing characteristics, has been reported [7] with a potential to produce DM yield as shown in Table 1.

Table 1. Napier dry matter yield.

\begin{tabular}{cc}
\hline Dry matter $(\mathrm{DM})$ yield & Reference \\
\hline 78 tons $\cdot \mathrm{ha}^{-1} \cdot \mathrm{yr}^{-1}$ & {$[19]$} \\
80 tons $\cdot \mathrm{ha}^{-1} \cdot \mathrm{yr}^{-1}$ & {$[20]$} \\
70 tons $\cdot \mathrm{ha}^{-1} \cdot \mathrm{yr}^{-1}$ & {$[21]$} \\
\hline
\end{tabular}

\subsection{Agronomical Practices}

Suitable conditions for Napier grass include well-drained medium-textured soils, soil $\mathrm{pH}$ from 4.5 to 8.2 , precipitation from 750 to $2500 \mathrm{~mm} \cdot \mathrm{yr}^{-1}$ with optimum temperature from $25^{\circ} \mathrm{C}$ to $40^{\circ} \mathrm{C}$ [22] [23]. Reference [5] noted that Napier could tolerate drought for a short spell and regenerate with rains. Areas receiving average annual rainfall of more than $1910 \mathrm{~mm}$ are envisaged to register a high DM yield of approximately 26.5 tons/ha/yr and cutting intervals of 7 weeks compared to 5.5 tons/ha dry matter from areas with $612 \mathrm{~mm}$ of average annual rainfall. Crop development does not progress under a base temperature of $15^{\circ} \mathrm{C}$ and is sensitive to frost, though it can regrow from the stolons if the soil is not frozen [24]. Relatedly, [20] reported a base temperature of $10^{\circ} \mathrm{C}$ for growth to progress. Reference [3] indicated that to improve forage quality, commercial forage producers need to implement better forage agro-ecological practices (38\%), followed better soil testing and feed standard facilities (25\%) and feed by the use of improved/new varieties (21\%). Another study by [25] showed that using improved forage technologies (IFT) required lower total production costs per season, and higher average milk production per cow per season compared to the farmers using traditional technology. As such, they had significantly five times higher revenues and gross margin than farmers using traditional forage technologies. 
Currently practiced agro-ecological practices include crop rotation, intercropping [26], multi cropping, crop diversification and soil fertilization. Agroecological practices involved use of intercrop for Maize-Cowpeas, Maize-lablab, Sorghum-lablab, Sorghum-cowpeas, Chloris gayana-Desmodium-Siratro, Elephant grass-Desmodium intortum mixture and Elephant grass occasionally supplemented with grazing. With the exceptional of irrigation, commonly used local agronomical practices were followed in all respects. Reference [21] in China observed that the interaction of irrigation and application of $300 \mathrm{~kg} \mathrm{~N} \cdot \mathrm{ha}^{-1}$ could possibly reach a DM yield potential of 12 ton $\cdot \mathrm{ha}^{-1}$ compared to no irrigation.

\section{Water Management Constraints}

\subsection{Water Limited Conditions}

The sustainability of irrigated agriculture is mostly threatened by increasing scarcity of water. According to [23] water for forage crops remains the most critical factor in Uganda. In regions where dairy farming is predominant, Napier is grown in irrigated upland situation. Reference [27] noted that $80 \%$ of the yield occurs during the rainy season, thus the forage production is highly susceptible to seasonal water stress due to either waterlogging or drought. Reference [28] observed that Napier is expected to experience lengthy rainfall fluctuations which might prompt water stress during a growing period since it is a perennial crop. Moreover, yield potential of some cultivars reduces by $20 \%$ when grown under water-deficient conditions compared to a control environment [28]. Therefore, seasonality of fodder as a consequence of climate change is one of the major constraints in meeting agro-pastoral demands in Uganda. It is occasioned by frequent and erratic droughts some of which are prolonged. Thus, integration of irrigation management strategies in Napier production is envisaged to avoid risks of yield penalty [4] [5] [21] [29]. However, [30] noted that irrigated agriculture is still practiced in many areas of the world with complete disregard to basic principles of resource conservation and its sustainability. Henceforth, irrigation water use amidst water scarcity requires efficient utilization aiming at maximizing its productivity [31].

\subsection{Water Use Inefficiency}

Water Use Efficiency (WUE) has long been recognized as a key constraint on crop production and a vital target for water management [30]. Consistent with [7], successful Napier production is influenced by the ability to attenuate the trade-off between DM production and potential yield when subjected to stress conditions. Napier grass undergoes adjustments in its morphology (i.e., reduced stomatal conductance, leaf rolling, and enhanced water use efficiency) when grown under water limited conditions [28]. An immediate relation therefore exists between biomass production and water consumed through transpiration [32]. Water stress and reduced transpiration result in a reduced biomass pro- 
duction that normally also reduces yields. Reference [5]'s study estimated that the minimum WUE of Napier coincides with the minimum ET as observed during fifth cut (Figure 2).

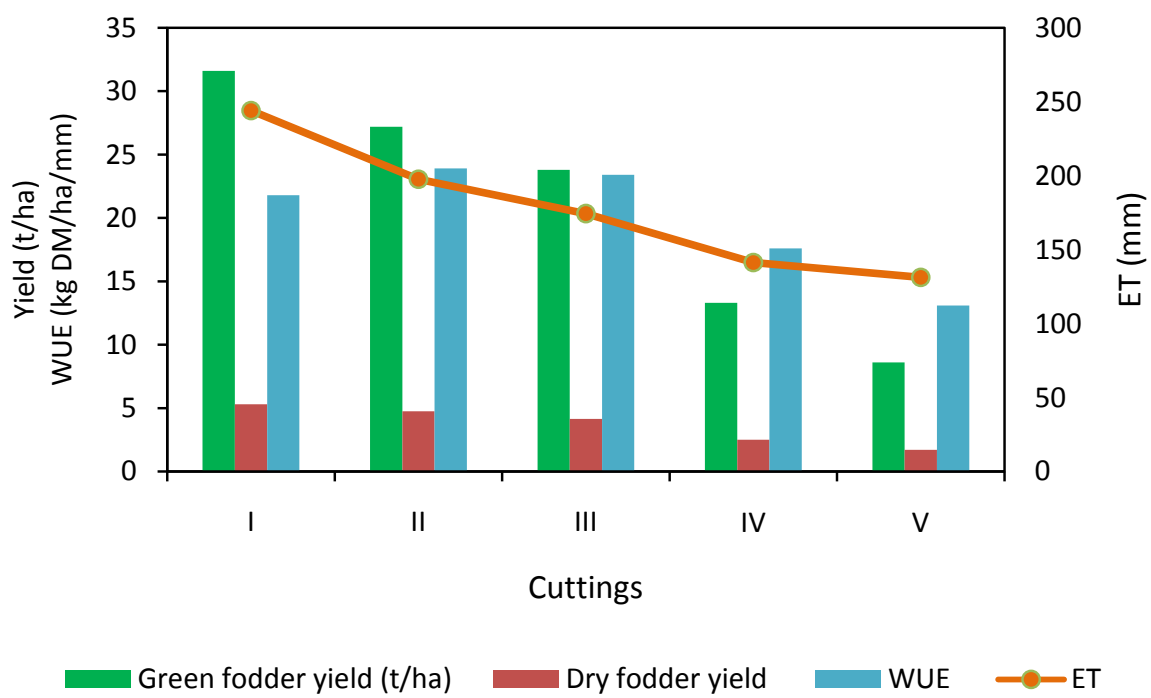

Figure 2. Mean crop evapotranspiration (ET) and water use efficiency (WUE) of Napier (Source: [5]).

The findings are consistent with [33] that yield response to water approach linked a reduction in evapotranspiration to a proportional reduction in yield. This implies that water supply limitations will likely impose greater constraints on future crop production across diverse growing regions and crop types, increasing the need to understand and improve WUE [34]. To better explore the impacts on Napier yield of optimized WUE by manipulating crop morphology, there is need to conduct a simulation study using the crop models.

\subsection{Inefficient Irrigation Scheduling}

Irrigation scheduling primarily aims at attenuating wasteful losses of water (percolation beyond what is necessary for salt leaching, surface runoff and evaporation) and maximizing transpiration, which is the valuable loss of water due to its direct link with dry matter production [35]. To achieve higher irrigation efficiency, water management must be improved through optimized irrigation scheduling [29] [36]. The results are consistent with [4]'s observations that the controlled and timely application of water through drip irrigation enhances fodder yields leading to more effective utilization and resource conservation of available water. Water management will not be reached if we have not considered the irrigation schedule and calculated the precise amounts of different crop water requirements. Consequently, water requirements from rivers, lakes and aquifers for irrigation will be under control. Therefore, irrigation scheduling under variable annual rainfall requires a good decision support tool (DST) to 
manage rainfall uncertainties. The yield function tends to be uncertain due to the effort in estimating the water losses to inefficient application (like evaporative losses), deep percolation and surface and subsurface runoff, particularly when variability of weather is associated.

Efficient irrigation scheduling methods such as irrigating based on a water budget i.e., crop evapotranspiration (ET) and soil water monitoring minimize over-irrigation while not affecting yields and subsequently decreasing nutrient leaching [29] [37]. The ET estimation approach involves computing the reference evapotranspiration (ETo) using meteorological data (e.g., temperature, solar radiation, relative humidity, and wind speed). Widely accepted equations for estimating ETo are the Food and Agricultural Organization of the United Nations (FAO) Penman-Monteith [38] and the American Society of Civil Engineers-Environmental and Water Resources Institute (ASCE-EWRI 2005). Crop coefficients (Kc) relate evapotranspiration from the reference crop (ETo) to evapotranspiration rates (ETa) of a crop of interest (i.e., ETa is a product of Kc and ETo) [38]. The availability of Kc values is one of the limitations of using ET-based irrigation scheduling because time and financial resources are required to develop kc values, and once developed, they remain cultivar, site, stage of crop growth, plant size, and site specific.

Changes in crop morphology play a fundamental role in regulating water-use efficiency, they present a key target for improving WUE. Soil water sensors have been used to estimate soil moisture in the root zone [39]. These can be integrated with irrigation control equipment to automate irrigation scheduling at set soil water stress thresholds. Specific soil water stresses include canopy expansion, allowable depletion, stomatal closure, and canopy senescence each with a threshold depletion level. Reference [40] observed that an allowable depletion level that avoids stomatal closure should be selected if drought stress during the sensitive growth stages only has a negative effect on the Harvest Index (HI). The limitation with irrigation scheduling based on soil water content monitoring is brought about by the cost to represent the range of conditions in the field.

\section{Irrigation Water Management Strategies}

\subsection{Precision Irrigation}

Reference [41] noted that irrigation management must put into consideration characteristics such as water requirements (e.g., seasonal, average, annual and daily water use), root system development, critical stages of growth, soil characteristics, irrigation system, and available water supply. While variations in yield between cultivars can be large [17], the variation in water use under optimum irrigation is much smaller, as water use is primarily controlled by evaporative demand [38]. This is because under conditions where water is scarce, water productivity (WP) may be more important to the farmer than an emphasis on production per unit area [42]. Reference [42] examined strategies to improve the water productivity of irrigated Napier systems to remain economically viable. 
These included modification of irrigation strategies to reduce water use whilst maintaining WP and using cultivars that can survive and still be productive under reduced irrigation and then recover when full irrigation is restored. A similar observation by [43] pointed to the fact that the actual irrigation depths caused a quadratic response on pasture yield. In an attempt to optimize water use for irrigation, there is significant uncertainty in the anticipated yield results and, often the alternatives that anticipate higher net returns also have higher risks [30]. Conversely, precision irrigation (PI) or irrigation depths that applied water volumes close to ETo promoted considerable increases in yields. PI corresponds to the water requirement enabling the actual crop evapotranspiration to be equal to its potential evapotranspiration [44]. Therefore, integration of irrigation in Napier production is envisaged to avoid risks of yield penalty [4] [20]. Reference [43] noted that studies related to fodder yield responses to different irrigation depths are hardly in the literature. Henceforth, there is a dire need to close the knowledge gap on response of Napier productivity to different irrigation water management strategies [6].

\subsection{Deficit Irrigation}

The functionality of irrigation is not only to provide sufficient water for crops in order to achieve better outcome in production, as implied in conventional irrigation definition but must be also contributing to improving the features such as WUE [4], crop water productivity, and water saving potential. Deficit Irrigation (DI) refers to a variable management strategy and its effective implementation is dependent on a thorough irrigation schedule, in terms of both application amount and timing. Therefore, there exist several possibilities (e.g., growth-stage-specific DI, intermittent DI (irrigation is applied on specific days) [39], and root zone soil moisture depletion) when exploring and implementing a DI management approach. In each case, [40] observed that different water depths can be applied. Reference [21] observed that applying $0.5 \times \mathrm{ET}_{0}$ increases Napier's DM yield by $44 \%$ compared to production under rain-fed conditions. A validation by [45] observed that a slight decrease of yield in the earlier phenological stages could be compensated in the later stages when applying DI. It has been successfully applied in dry regions overseas to improve WUE in many horticultural and annual crops [46]. According to [40], DI is an optimization management strategy in which irrigation is only applied during water stress sensitive growth stages of a crop. An analysis by [40] also imparts that by selecting an allowable depletion level that avoids severe water stress (i.e., when the available soil water is far below the stomata closure threshold) during sensitive crop growth stages, Water Productivity (WP) and Harvest Index (HI) can be maximized. So, inevitability there is a need to optimally determine the level of depletion during the sensitive crop growth stages to avoid inducing stomatal closure. Similarly, [47] acknowledged that identifying optimal DI strategies can potentially save water without 
imposing yield penalties during crop growth. However, its application on forage crops has not been extensively explored in Uganda. Thus, accurate information on the response of Napier to water shortages is required, if implementation of a deficit irrigation strategy is to be successful. Therefore, undertaking studies relating water regimes of Napier that subsidize the choice of the irrigation system and its management is long-awaited [43] [45] [48]. A similar observation by [29] indicated that the relationship between the crop water stress and yield is very important in scheduling for deficit irrigation. A point in case is canopy expansion stress threshold for Napier grass which is triggered at $50 \%$ of available soil water under controlled greenhouse conditions [28]. Irrigation scheduling based on soil water content monitoring is most triggered at $40 \%-50 \%$ of allowable depletion determined by constantly monitoring the soil water status and estimated as follows in Equation (1):

$$
\operatorname{Depletion}(\%)=100 \times \frac{1}{n} \sum_{1}^{n} \frac{F C_{i}-\theta_{i}}{F C_{i}-W P^{\prime}} .
$$

where $n$ is the number of sub-divisions of the effective rooting depth used in the soil moisture sampling, $F C_{i}$ is the soil moisture at field capacity for th layer, $\theta_{i}$ is the soil moisture in th layer, and $W P$ is the soil moisture at permanent wilting point.

\subsection{Application of Biophysical Models}

The complexity of crop responses to water deficits had often led to the utilization of empirical production functions as the most practical choice to assess crop yield response to water. Crop growth simulation models have been illustrated to be powerful tools that can provide pre-season decision-making on cropping patterns and irrigation strategies. Biophysical models have a pivotal role to play in evaluating irrigation management strategies for improving agricultural water use and exploration of new practices [49]. The FAO AquaCrop model is less costly and utilized in objective decision-making and in the selection of crops prioritized for irrigation in areas of limited water resources [50]. The model introduced relative simplifications and a small number of crop parameters to typify the crop than other models without negatively affecting its performance in terms of biomass. AquaCrop enables the user to simulate the combined positive and negative effects of drought stress on HI adjustment during yield formation and to derive the mathematically optimal level of depletion during sensitive growth stages. It has successfully been parameterized to simulate crop growth and yield as influenced by varying soil moisture environments for crops like rice [50] [51], maize [52] [53], cabbage [54], cotton [36], barley [55], sunflower, Bambara groundnut [56], and wheat [57] [58] [59]. Reference [36] illustrated the potential of AquaCrop model by developing irrigation scheduling scenarios in cotton production. The results showed that peak irrigation water productivity is obtained by application of a single irrigation at the seedling stage in a wet year, two 
irrigation events at the seedling and squaring stages during a normal year and three irrigation events at the seedling, squaring and flowering stages during a dry year. Reference [40] used the AquaCrop model to establish a linkage between yield response of Quinoa (Chenopodium quinoa Willd.) and varying irrigation water management strategies through development of DI schedules. The findings indicated that for a field with medium developed dry biomass production (B) at anthesis, irrigation should be applied every 5 days between 70 and 100 days after sowing (DAS) and every 4 days between 100 and 120 DAS. In eventualities of poor $B$ development until anthesis, the irrigation frequency should be lower (every 7 days) between 70 and 90 DAS, but is similar to the former case between 90 and 120 DAS.

\section{Future Perspective}

A combination of field experiments and series of climate data with crop modeling is envisaged to enrich the experimental study results by developing scenarios not previously considered [60]. Scenario to be developed include 1) irrigation schedules for maximum production (e.g., in dry, normal, wet year); 2) comparison between attainable and actual yields in fields; 3) crop responses to different agronomic practices; and 4) best use of stored soil water when irrigation supply is limited. A field research experiment will be conducted in this regard to provide an opportunity to assess the effect of irrigation water management strategies on Napier productivity [24] [43] [45] [48]. Reference [49] noted that AquaCrop Model results obtained from representative fields are can be utilized to upscale field productivities to the watershed level. If upscaled to other crops and basins, the presented strategy can be a simple and illustrative decision support tool for sustainable intensification.

\section{Conclusion}

As demonstrated by the study, it is evident that there is inadequate information on response of Napier productivity to different irrigation water management strategies. Numerous strategies including precision irrigation, deficit irrigation and crop modelling have been assessed and implemented from the perspective of water resource conservation and its sustainability and maximizing productivity. However, in an attempt to optimize irrigation water, there is significant uncertainty in the anticipated yield results and, often the alternatives that anticipate higher net returns also have higher costs involved and risks. To reduce uncertainty and risk, biophysical models like the FAO AquaCrop that simulate irrigation performance indicate potential to aid in assisting water managers to optimize a limited supply of irrigation water and developing scenario simulations. Unlike fodder crops, most herbaceous food crops have their built-in crop parameters in the AquaCrop model, therefore it is very imperative to first parameterize the model using experimental data. 


\section{Acknowledgements}

The authors are thankful to the Lecturers and colleagues at the Department of Agricultural and Biosystems Engineering, Makerere University for their instrumental efforts which made this review a success.

\section{Conflicts of Interest}

All authors declare that they have no potential competing interests.

\section{References}

[1] Kabirizi, J., Muyekho, F., Mulaa, M. and Pallangyo, B. (2015) Napier Grass Feed Resource: Production, Constraints and Implications for Smallholder Farmers in East and Central Production, Constraints and Farmers in Eastern and Central.

[2] Marais, D., et al. (2002) Water Use and Water Use Efficiency of Fodder Crops under Irrigation: Part 1 Annual Subtropical Crops.

[3] Creemers, J. and Aranguiz, A. (2019) Quick Scan of Uganda's Forage Sub-Sector.

[4] Jha, A.K., Malla, R., Sharma, M., Panthi, J., Lakhankar, T., Krakauer, N.Y., Shrestha, M.L., et al. (2016) Impact of Irrigation Method on Water Use Efficiency and Productivity of Fodder Crops in Nepal. Climate, 4, 4. https://doi.org/10.3390/cli4010004

[5] Singh, J.B., Agrawal, R.K. and Behari, P. (2004) Water Use Efficiency and Evapotranspiration of Hybrid Napier (Pennisetum purpureum $x$ P. americanum) under Semi-Arid Indian Region. Indian Journal of Range Management, 17-18.

[6] Epule, T.E., Ford, J.D., Lwasa, S., Nabaasa, B. and Buyinza, A. (2018) The Determinants of Crop Yields in Uganda: What Is the Role of Climatic and Non-Climatic Factors? Agriculture and Food Security, 7, Article No. 10. https://doi.org/10.1186/s40066-018-0159-3

[7] Negawo, A.T., Teshome, A., Kumar, A., Hanson, J. and Jones, C.S. (2017) Opportunities for Napier Grass (Pennisetum purpureum) Improvement Using Molecular Genetics. Agronomy, 7, Article No. 28. https://doi.org/10.3390/agronomy7020028

[8] Buyinza, J., Sekatuba, J., Ongodia, G., Eryau, K., Nansereko, S., Opolot, I.V., Agaba, H., et al. (2015) Farmers' Knowledge on Forage Production in Smallholder Dairy Systems of Uganda. International Journal of Livestock Production Research, 3, 1-10.

[9] Rengsirikul, K., Ishii, Y., Kangvansaichol, K., Sripichitt, P., Punsuvon, V., Vaithanomsat, P. and Tudsri, S. (2013) Biomass Yield, Chemical Composition and Potential Ethanol Yields of 8 Cultivars of Napier Grass (Pennisetum purpureum Schumach.) Harvested 3-Monthly in Central Thailand. Journal of Sustainable Bioenergy Systems, 3, 107-112. https://doi.org/10.4236/jsbs.2013.32015

[10] Orodho, A.B. (2006) The Role and Importance of Napier Grass in the Smallholder Dairy Industry in Kenya. Food and Agriculture Organization, Rome.

http://www.fao.org/ag/AGP/AGPC/doc/Newpub/napier/napier kenya.htm\%0Ahttp ://www.fao.org/ag/agp/agpc/doc/newpub/napier/napier kenya.htm

[11] Akah, N.P. and Onweluzo, J.C. (2014) Evaluation of Water-Soluble Vitamins and Optimum Cooking Time of Fresh Edible Portions of Elephant Grass (Pennisetum purpureum L. Schumach) Shoot. Nigerian Food Journal, 32, 120-127. https://doi.org/10.1016/S0189-7241(15)30127-2

[12] Kabirizi, J., Ziiwa, E., Mugerwa, S., Ndikumana, J. and Nanyennya, W. (2013) Dry Season Forages for Improving Dairy Production in Smallholder Systems in Uganda. 
Tropical Grasslands Forrajes Tropicales, 1, 212-214. https://doi.org/10.17138/TGFT(1)212-214

[13] Keba, H.T., Madakadze, I.C., Angassa, A. and Hassen, A. (2013) Nutritive Value of Grasses in Semi-Arid Rangelands of Ethiopia: Local Experience Based Herbage Preference Evaluation versus Laboratory Analysis. Asian-Australasian Journal of Animal Sciences, 26, 366-377. https://doi.org/10.5713/ajas.2012.12551

[14] Okwori, A.I. and Magani, I.E. (2010) Influence of Nitrogen Sources and Cutting Interval on the Digestility of Four (4) Grass Species in the Southern Guinea Savanna of Nigeria. Agriculture and Biology Journal of North America, 1, 526-533. http://scihub.org/ABJNA/PDF/2010/4/1-4-526-533.pdf

[15] Wangchuk, K., Rai, K., Nirola, H., Thukten, Dendup, C. and Mongar, D. (2015) Forage Growth, Yield and Quality Responses of Napier Hybrid Grass Cultivars to Three Cutting Intervals in the Himalayan Foothills. Tropical Grasslands Forrajes Tropicales, 3, 142-150. https://doi.org/10.17138/TGFT(3)142-150

[16] Amin, R., Ram, N., Yousuf, S., Hashem, A. and Khatun, M. (2016) Study on Cutting Intervals on Biomass Yield, Nutritive Value and Their Oxalate Content of Different High Yielding Napier (P. purpureum) Cultivars. Bioscience and Biotechnology, 1, 100-107.

[17] Sarker, N.R., Habib, M.A., Yeasmin, D., Tabassum, F. and Mohammed, R.A. (2021) Studies on Biomass Yield, Morphological Characteristics and Nutritive Quality of Napier Cultivars under Two Different Geo-Topographic Conditions of Bangladesh. American Journal of Plant Sciences, 12, 914-925. https://doi.org/10.4236/ajps.2021.126061

[18] Kebede, G., Feyissa, F., Assefa, G., Alemayehu, M., Mengistu, A., Kehaliew, A., Abera, M., et al. (2016) Chemical Composition and In-Vitro Organic Matter Digestibility of Napier Grass (Pennisetum purpureum (L.) Schumach) Accessions in the Mid and Highland Areas of Ethiopia. International Journal of Livestock Research, 6, 41. https://doi.org/10.5455/ijlr.20160317124016

[19] Maria, L.F.O., Rogrio, F.D., de Geraldo, A.G., da Vernica, B.S., Erina, V.R., Aldo, S., dos Avelino, S.R., et al. (2014) Pre-Breeding of Elephant Grass for Energy Purposes and Biomass Analysis in Campos dos Goytacazes-RJ, Brazil. African Journal of Agricultural Research, 9, 2743-2758. https://doi.org/10.5897/AJAR2014.8900

[20] Singh, B.P., Singh, H.P. and Obeng, E. (2013) 13 Elephantgrass. In: Singh, B.P., Ed., Biofuel Crops: Production, Physiology and Genetics, CABI, Georgia, USA, 271-291.

[21] Norsuwan, T., Marohn, C. and Jintrawet, A. (2014) Effects of Irrigation Treatments and Nitrogen Applications on Napier Grass Planted in Dry Season as Energy Crop at Chiang Mai Province. Khon Kaen Agricultural Journal, 42, 1-7.

[22] Moore, G., Sanford, P. and Wiley, T. (2006) Perennial Pastures for Western Australia. 248.

[23] FAO (Food and Agriculture Organization) (2019) The Future of Livestock in Uganda. Opportunities and Challenges in the Face of Uncertainty. Rome.

[24] Mwendia, S.W., Yunusa, I.A.M., Sindel, B.M., Whalley, R.D.B. and Kariuki, I.W. (2017) Assessment of Napier Grass Accessions in Lowland and Highland Tropical Environments of East Africa: Water Stress Indices, Water Use and Water Use Efficiency. Journal of the Science of Food and Agriculture, 97, 1953-1961. https://doi.org/10.1002/jsfa.8004

[25] Turinawe, A., Mugisha, J. and Kabirizibi, J. (2011) Socio-Economic Evaluation of Improved Forage Technologies in Smallholder Dairy Cattle Farming Systems in 
Uganda. Journal of Agricultural Science, 4, 163-174.

https://doi.org/10.5539/jas.v4n3p163

[26] Cheruiyot, D., Midega, C.A.O., Pittchar, J.O., Pickett, J.A. and Khan, Z.R. (2020) Farmers' Perception and Evaluation of Brachiaria Grass (Brachiaria spp.) Genotypes for Smallholder Cereal-Livestock Production in East Africa. Agriculture (Switzerland), 10, 268. https://doi.org/10.3390/agriculture10070268

[27] Thaiana Rueda da Silva, C., Bonfim-Silva, E.M., de Araújo da Silva, T.J., Alves Rodrigues Pinheiro, E., Vieira José, J. and Pereira Freire Ferraz, A. (2020) Yield Component Responses of the Brachiaria brizantha Forage Grass to Soil Water Availability in the Brazilian Cerrado. Agriculture, 10, 13.

https://doi.org/10.3390/agriculture10010013

[28] Purbajanti, E.D., Anwar, S. and Kusmiyati, F. (2012) Drought Stress Effect on Morphology Characters, Water Use Efficiency, Growth and Yield of Guinea and Napier Grasses. International Research Journal of Plant Science, 3, 47-53.

[29] Vennila, C. and Ananthi, T. (2019) Impact of Irrigation and Nutrients on the Performance of Bajra Napier Hybrid Grass Grown under Light Sandy Soil. International Journal of Current Microbiology and Applied Sciences, 8, 804-812. https://doi.org/10.20546/ijcmas.2019.806.097

[30] Getiso, A. and Mijena, D. (2021) Performance Evaluation of Napier Grass (Pennisetum purpureum (L.) Schumach) Accessions under Rain Fed and Irrigation System at Wondo Genet. Global Journal of Ecology, 6, 28-33.

[31] Fereres, E. and Soriano, M.A. (2007) Deficit Irrigation for Reducing Agricultural Water Use. Journal of Experimental Botany, 58, 147-159.

https://doi.org/10.1093/jxb/erl165

[32] Steduto, P., Hsiao, T.C., Raes, D. and Fereres, E. (2009) Aquacrop-The FAO Crop Model to Simulate Yield Response to Water: I. Concepts and Underlying Principles. Agronomy Journal, 101, 426-437. https://doi.org/10.2134/agronj2008.0139s

[33] Doorenbos and Kassam (1979) Yield Response to Water. FAO Irrigation and Drainage, Rome. https://doi.org/10.1016/B978-0-08-025675-7.50021-2

[34] Leakey, A.D.B., Ferguson, J.N., Pignon, C.P., Wu, A., Jin, Z., Hammer, G.L. and Lobell, D.B. (2019) Water Use Efficiency as a Constraint and Target for Improving the Resilience and Productivity of C 3 and C 4 Crops. Annual Review of Plant Biology, 70, 781-808. https://doi.org/10.1146/annurev-arplant-042817-040305

[35] Annandale, J.G., Stirzaker, R.J., Singels, A., van der Laan, M. and Laker, M.C. (2011) Irrigation Scheduling Research: South African Experiences and Future Prospects. Water SA, 37, 751-764. https://doi.org/10.4314/wsa.v37i5.12

[36] Li, F., Yu, D. and Zhao, Y. (2019) Irrigation Scheduling Optimization for Cotton Based on the AquaCrop Model. Water Resources Management, 33, 39-55. https://doi.org/10.1007/s11269-018-2087-1

[37] Kiggundu, N. and Migliaccio, K.W. (2012) Water Savings, Nutrient Leaching, and Fruit Yield in a Young Avocado Orchard as Affected by Irrigation and Nutrient Management. Irrigation Science, 30, 275-286.

https://doi.org/10.1007/s00271-011-0280-6

[38] Allen, R.G., Pereira, L.S., Raes, D., et al. (1998) Crop Evapotranspiration: Guidelines for Computing Crop Water Requirements. Agronomy, 10, 269-280.

[39] Nakawuka, P., Peters, T.R. and Gallardo, K.R. (2014) Effect of Deficit Irrigation on Yield, Quality, and Costs of the Production of Native Spearmint. Journal of Irrigation and Drainage Engineering, 140, 1-9. 
https://doi.org/10.1061/(ASCE)IR.1943-4774.0000719

[40] Geerts, S., Raes, D. and Garcia, M. (2010) Using AquaCrop to Derive Deficit Irrigation Schedules. Agricultural Water Management, 98, 213-216. https://doi.org/10.1016/j.agwat.2010.07.003

[41] Irmak, S., DeLyann, R.H., Anderson, B.E., Kranz, L.W., et al. (2007) Irrigation Management and Crop Characteristics of Alfalfa. IEEE Wireless Communications and Networking Conference, Vol. 1, 196-201.

[42] Rogers, M.J., Lawson, A. and Kelly, K. (2017) Forage Options for Dairy Farms with Reduced Water Availability in the Southern Murray Darling Basin of Australia. Sustainability (Switzerland), 9, 1-20. https://doi.org/10.3390/su9122369

[43] Antoniel, L.S., do Prado, G., Tinos, A.C., Beltrame, G.A., de Almeida, J.V.C. and Cuco, G.P. (2016) Pasture Production under Different Irrigation Depths. Revista Brasileira de Engenharia Agricola e Ambiental, 20, 539-544. https://doi.org/10.1590/1807-1929/agriambi.v20n6p539-544

[44] Frenken, K. and Gillet, V. (2012) Irrigation Water Requirement and Water Withdrawal by Country. AQUASTAT Report, 13.

[45] Tian, Y., Liu, Y. and Jin, J. (2017) Effect of Irrigation Schemes on Forage Yield, Water Use Efficiency, and Nutrients in Artificial Grassland under Arid Conditions. Sustainability (Switzerland), 9, 57-66. https://doi.org/10.3390/su9112035

[46] Neal, J.S., Fulkerson, W.J. and Sutton, B.G. (2011) Differences in Water-Use Efficiency among Perennial Forages Used by the Dairy Industry under Optimum and Deficit Irrigation. Irrigation Science, 29, 213-232. https://doi.org/10.1007/s00271-010-0229-1

[47] Dirwai, T.L., Senzanje, A. and Mabhaudhi, T. (2021) Calibration and Evaluation of the FAO AquaCrop Model for Canola (Brassica napus) under Varied Moistube Irrigation Regimes. Agriculture, 11, 410. https://doi.org/10.3390/agriculture11050410

[48] Sebata, A. (2018) An Insight into Current and Future Production of Forage Crops in Zimbabwe. In: New Perspectives in Forage Crops, InTechOpen, London, 89-104. https://doi.org/10.5772/intechopen.71997

[49] Alaya, I., Masmoudi, M.M., Jacob, F. and Ben Mechlia, N. (2019) Up-Scaling of Crop Productivity Estimations Using the AquaCrop Model and GIS-Based Operations. Arabian Journal of Geosciences, 12, Article No. 419. https://doi.org/10.1007/s12517-019-4588-5

[50] Maniruzzaman, M., Talukder, M.S.U., Khan, M.H., Biswas, J.C. and Nemes, A. (2015) Validation of the AquaCrop Model for Irrigated Rice Production under Varied Water Regimes in Bangladesh. Agricultural Water Management, 159, 331-340. https://doi.org/10.1016/j.agwat.2015.06.022

[51] Sandhu, S.S., Mahal, S.S. and Kaur, P. (2015) Calibration, Validation and Application of AquaCrop Model in Irrigation Scheduling for Rice under Northwest India. Journal of Applied and Natural Science, 7, 691-699. https://doi.org/10.31018/jans.v7i2.668

[52] Greaves, G.E. and Wang, Y.M. (2016) Assessment of FAO Aquacrop Model for Simulating Maize Growth and Productivity under Deficit Irrigation in a Tropical Environment. Water (Switzerland), 8, 557. https://doi.org/10.3390/w8120557

[53] Mibulo, T. and Kiggundu, N. (2018) Evaluation of FAO AquaCrop Model for Simulating Rainfed Maize Growth and Yields in Uganda. Agronomy, 8, 238.

https://doi.org/10.3390/agronomy8110238 
[54] Pawar, G.S., Kale, M.U. and Lokhande, J.N. (2017) Response of AquaCrop Model to Different Irrigation Schedules for Irrigated Cabbage. Agricultural Research, 6, 73-81. https://doi.org/10.1007/s40003-016-0238-2

[55] Araya, A., Habtu, S., Hadgu, K.M., Kebede, A. and Dejene, T. (2010) Test of AquaCrop Model in Simulating Biomass and Yield of Water Deficient and Irrigated Barley (Hordeum vulgare). Agricultural Water Management, 97, 1838-1846. https://doi.org/10.1016/j.agwat.2010.06.021

[56] Karunaratne, A.S., Azam-Ali, S.N., Izzi, G. and Steduto, P. (2011) Calibration and Validation of FAO-Aquacrop Model for Irrigated and Water Deficient Bambara Groundnut. Experimental Agriculture, 47, 509-527. https://doi.org/10.1017/S0014479711000111

[57] Mansour, H.A., Gaballah, M.S. and Nofal, O.A. (2020) Evaluating the Water Productivity by Aquacrop Model of Wheat under Irrigation Systems and Algae. Open Agriculture, 5, 262-270. https://doi.org/10.1515/opag-2020-0029

[58] Jin, X.L., Feng, H.K., Zhu, X.K., Li, Z.H., Song, S.N., Song, X.Y., Guo, W.S., et al. (2014) Assessment of the AquaCrop Model for Use in Simulation of Irrigated Winter Wheat Canopy Cover, Biomass, and Grain Yield in the North China Plain. PLoS ONE, 9, e86938. https://doi.org/10.1371/journal.pone.0086938

[59] Silvestro, P.C., Pignatti, S., Yang, H., Yang, G., Pascucci, S., Castaldi, F. and Casa, R. (2017) Sensitivity Analysis of the Aquacrop and SAFYE Crop Models for the Assessment of Water Limited Winter Wheat Yield in Regional Scale Applications. PLoS ONE, 12, e0187485. https://doi.org/10.1371/journal.pone.0187485

[60] Mwiya, R.M., Zhang, Z., Zheng, C. and Wang, C. (2020) Comparison of Approaches for Irrigation Scheduling Using AquaCrop and NSGA-III Models under Climate Uncertainty. Sustainability (Switzerland), 12, 7694.

https://doi.org/10.3390/su12187694 